\title{
ARISTONICUS, BLOSSIUS, AND THE CITY OF THE SUN
}

In Asia Minor in the Second Century B.C., an ephemeral revolutionary regime held sway which has been variously hailed as the first volley of Marxism ${ }^{1}$ or the last stand of Cloudcuckooland. ${ }^{2}$ Since Aristonicus did not hesitate to openly proclaim class warfare against the bourgeoisie of Pergamum, even restrained scholars label his City of the Sun as a "proletarian state". ${ }^{3}$ Ironically, though he challenged the majesty of Rome, Aristonicus won the support of Blossius of Cumae, the Stoic adviser of Tiberius Gracchus and the ideologue of the Roman reformers, who would perish in the debacle of the Pergamene revolution.

In I 33 B.C., Attalus III of Pergamum and Tiberius Gracchus died; the tribune was clubbed to death but the king became a god. ${ }^{4}$ According to legend, Attalus lacked few of the stock villainies of a stage tyrant. Misanthropic and slightly mad, he murdered his relatives and mourned them excessively, dabbled in science and metallurgy, and distilled deadly poisons from a garden of noxious plants. ${ }^{5}$ However, Attalus was also a capable administrator who managed his realm efficiently. Since the kingdom was a center of trade and industry, the crown derived revenue from the production of pitch, parchment, and textiles, but the chief source of royal income were the great farms and grazing lands, worked by semi-serfs and royal slaves. ${ }^{6}$ Successively

1 Robert von Pöhlmann, Geschichte der sozialen Frage und des Sozialismus in der antiken Welt, Munich (Ed. 3 Oertel) i 925, I, pp. 405-406.

${ }^{2}$ Arnold J. Toynbee, A Study of History, London i939, VI, p. $35 \mathrm{I}$.

${ }^{3}$ Joseph Vogt, Struktur der antiken Sklavenkriege, in: Akademie der Wissenschaften und der Literatur, Abh. der geistes- und- sozialwissenschaftlichen Klasse (1957) r, p. 22.

${ }^{4}$ See Esther Hansen, The Attalids of Pergamon, Cornell, 1947, pp. 410-426, on the posthumous cult of the Attalids.

${ }_{5}^{5}$ Justin XXXVI 4. Diodorus XXXIV 3. Cf. Hansen, pp. I34-I4I, and David Magie, Roman Rule in Asia Minor, Princeton r950, I, pp. 30-33.

${ }^{6}$ Hansen, pp. 153-21 7. M. Rostovtzeff, in: Cambridge Ancient History, VIII, pp. 590-618, and Social and Economic History of the Hellenistic World, Oxford 1941, I, p. 509, emphasizes the isolation of laoi in villages and farms which may have increased their revolutionary potential. 
standing off Seleucid and Gaul and still threatened by neighboring dynasts, Pergamum had looked westward for aid and found a willing ally in Rome whose agents in Asia the Attalids were in effect from the reign of Eumenes II. Before he "withdrew from mankind", Attalus III willed to the Roman people his personal treasure and royal estates, specifying that Pergamum and other Greek cities with their territories, as well as temple lands, were excluded from the bequest, ${ }^{1}$ a technicality of little weight to the imperial heirs. While the king may have simply anticipated the arrival of Rome and merely checkmated his greedy neighbors, Attalus the man sought to circumvent any claim of his bastard half-brother, Aristonicus. The will was received with delight by the Gracchan reformers at Rome, in need of cash to implement their land program, but the august fathers of the Senate looked askance at the grand manner in which Tiberius Gracchus accepted the bequest in the name of the people, usurping the senatorial monopoly of foreign affairs. ${ }^{2}$ Already exacerbated by the Gracchan encroachments on inclosed public lands, conservatives were infuriated at the constitutional threat posed by the tribune's action. Previously in deposing a rival tribune, Tiberius Gracchus had created a de facto popular tyranny, ${ }^{3}$ and when he further defied convention by seeking reelection, the opposition panicked. Since the Gracchan consul, P. Mucius Scaevola, refused to act, the Pontifex Maximus, P. Scipio Nasica, led a senatorial mob to lynch the tribune in defense of property and propriety. ${ }^{4}$ Though a selective massacre ensued and the body of Tiberius Gracchus was flung into the Tiber by night, his program continued, shorn of its threat of dictatorship. As the Gracchan purge of 132 subsided, the land commission still sat and the Senate looked eagerly at its new preserves in Asia, dispatching Scipio Nasica as legate with four others to organize the new province, possibly as a salve to public opinion. ${ }^{5}$ Soon Nasica died in Asia where a grave also awaited P. Licinius Crassus who succeeded him as Pontifex Maximus and took as well the murdered tribune's seat on the land commission. However, there was a new Attalid at Pergamum.

\footnotetext{
'Magie, I, pp. 32-33. Hansen, p. 140. Sallust, Hist. IV 69.8. claims that the will was forged, a charge perhaps not unfounded in particulars of the bequest.

2 Plutarch, Tiberius Gracchus 14 . Gracchan connections with Pergamene circles are ably described by E. Badian, Foreign Clientelae, Oxford 1958, pp. 173-174.

${ }^{3}$ Plutarch, Tiberius Gracchus I5. While not intent on personal dictatorship, Tiberius Gracchus was as impatient of constitutional obstructions as Sulla or Caesar. To Tories, he was a tyrant slain by patriots (Velleius II 3 ); to Blossius, he was a statesman unencumbered by legalistic niceties.

4 Ibid., 19-20. Appian, Bel. Civ. I I6-1 7.

5 Valerius Maximus V iii 2e. Plutarch, Tiberius Gracchus 2 I.
} 
Though his mother was an Ephesian concubine and the daughter of a harpist, ${ }^{1}$ Aristonicus' father was a king. Had Attalus III not died childless, the bastard of Eumenes II would have had little hope for a throne, but even a demi-Attalid was preferable to the rapacious republic which had blotted Carthage and Corinth from the earth and in a single day had enslaved I 50,000 Epirotes. ${ }^{2}$ Since Florus calls him "regii sanguinis ferox iuvenis", 3 the pretender was not without merit and even Magie concedes that "he was a man of boldness and ability"." Far more accurately than the burghers of Pergamum, Aristonicus sensed the mood of the masses; later the massacre of 80,000 "Romans" in the Mithridatic pogrom would give eloquent testimony that Asians preferred their own rulers to the publican's yoke. ${ }^{5}$ Blossius' presence alone gives some measure of the stature of Aristonicus. In raising the banner of national resistance to Rome, Aristonicus was not without precedent; Macedon had produced a bumper crop of pretenders, and one of the counterfeiters of Andriscus' claim, a former wife of Perseus, was married to a Pergamene. ${ }^{6}$ Utilization of explosive social conditions was not unique with Aristonicus. Recently, a Pseudo-Perseus had armed slaves in Macedon, ${ }^{7}$ a venerable Greek practice in time of stress, and there was general unrest among the servile population in the Aegean area. ${ }^{8}$ In Attica, the slaves in the Laurium mines rose and, in 130 , even those on Delos, the greatest of the slave marts, but these disturbances were simply spasms of agony in the slave community, like the great Sicilian revolt under the mantic Eunus who established an ephemeral realm as "King Antiochus" under the inspiration of a Syrian consort of the Sun. ${ }^{9}$ Though Aristonicus too appealed to rebellious slaves, his main support were the down-trodden serfs of the interior, for he failed markedly to win the cities, particularly

${ }_{1}$ Eutropius IV 20. Plutarch, Flamininus 2I. Justin XXXVI 4. Velleius Paterculus II 4 denies his claim to be a son of Eumenes II.

${ }^{2}$ Livy XLV 34 . The memory of the fate of Carthage and Corinth in 146 would still be fresh in Pergamum in 133.

3 Florus I xxxv 20.

4Magie I, p. I48. Generally Magie considers Aristonicus "a foe of Hellenic civilization" and "wholly unfitted to be king of Pergamum" (I:1 II; 32).

${ }^{5}$ Appian, Mith. 22-23. Rostovtzeff, SEHHW, II, pp. 938, 943. Sallust, Hist. IV 69.8 puts an eloquent defense of Aristonicus into the mouth of Mithridates Eupator.

${ }^{6} \mathrm{P}$. Benecke, in: Cambridge Ancient History, VIII, p. 276. Cf. Rostovtzeff, SEHHW, II, pp. 769-771, 977 .

7 Eutropius IV I 5 . Cf. Xenophon, Hellenica VI 5.28 and Thucydides IV 80.

${ }^{8}$ W. W. Tarn and G. Griffith, Hellenistie Civilization, London (Ed. 3) 1952, pp. 1 22-1 24.

${ }^{9}$ Florus II vii 19 . Diodorus XXXIV 2.13,39 describes the courtesy extended by the rebels to the humane daughter of a particularly hated master. Diodorus ascribes the same resentment of brutal treatment to the servile followers of Aristonicus. See F. Oertel, Die soziale Frage im Altertum, in: Forschungen und Fortschritte (1927) 3, pp. 257-258. 
Pergamum where the largest slave population was concentrated. Except for its final Helipolite phase, the Pergamene rebellion was a royalist Jacquerie rather than a Spartacus revolt, since Aristonicus claimed to seek a rightful throne, from which a wicked brother had excluded him, and was at this stage more Jacobite than Jacobin.

Probably shortly after the death of Attalus, ${ }^{1}$ the rebels seized Leucae and a portion of the Pergamene fleet. ${ }^{2}$ After Phocaea recognized the pretender, ${ }^{3}$ sea raids began ${ }^{4}$ and Samos, Myndus, Colophon, and possibly Notium fell. ${ }^{5}$ While Aristonicus' Thracian allies terrorized the Chersonesus, ${ }^{6}$ former royal mercenaries, many of them Thracians faced with unemployment, flocked to his standard. Though the rebel fleet harried the coast of Caria, Pergamum stood firm awaiting aid from Rome but grew alarmed at the prospects of a popular rising within the city. ${ }^{7}$ Because desertions were frequent and Aristonicus was known to have partisans within the metropolis, the bourgeoisie bridged the gap until the legions would arrive with an extraordinarily liberal decree:

“...Because King Attalus Motherlover and Benefactor, when he was removed from mankind, left our fatherland free and specified it and the public domain (and the Romans must ratify the bequest) and it is necessary for the public safety for the subjugated population to share citizenship in general harmony, the People made this decree. With good fortune, the People ordain to grant citizenship to the following: the resident aliens carried in the rolls; the soldiers settled in the city and its territory; and the Macedonians, Mysians, and Masdyans [?];... and resident troops throughout the city and its territory and their women and children, also those registered in the garrison of the old city. Into the rolls of resident aliens are entered the children of freedmen and the royal and public slaves, young and old, with their wives, except those royal slaves purchased in the reigns of Brotherlover [Attalus II] and Motherlover. But those inhabitants, who since the death of the

${ }^{1}$ Appian, Bel. Civ. I 18 states that Aristonicus was in revolt when Tiberius Gracchus was slain and quotes Sulla accusing the rebel cities of aiding the pretender for four years (133-129), Mith. 62, and returning only through fear and compulsion. Rostovtzeff, SEHHW, II, p. 825 accepts this view.

2 Strabo XIV 1.38.

${ }^{3}$ Justin XXXVII I.

4 Tacitus, Annals IV 55 and XII 62 cites Eastern cities claiming credit for resisting Aristonicus.

5 Florus I xxxv 20. See Magie I : 148.

6 Hansen p. I45. Rostovtzeff, SEHHW, II, p. 758.

7 Mithridates V executed fifth columnists in Pergamum. Cf. Magie, II, p. 1035. 
king have gone out of the city to the country, are declared outlaws and their property is to be confiscated by the city..." 1

Though the Roman legates lacked troops in the field, the client kings, Mithridates V of Pontus, Ariarathes V of Cappadocia, Nicomedes II of Bithynia, and Pylaemenes of Paphlagonia, closed in on the insurrection, eager for the rewards of service to Rome. ${ }^{2}$

In Rome, the consuls for $13 \mathrm{I}, \mathrm{P}$. Licinius Crassus and L. Valerius Flaccus, disputed the command of the punitive force to Asia. ${ }^{3}$ Since Flaccus was unlucky enough to hold the office of Flamen Martialis, his absence from Italy was reckoned more sacrilegious than that of the Pontifex Maximus who received the honor of liberating the treasure of Attalus. ${ }^{4}$ The father-in-law of Gaius Gracchus, ${ }^{5}$ Crassus was an accomplished linguist ${ }^{6}$ and a severe disciplinarian; ${ }^{7}$ Gellius marvelled that he was simultaneously "ditissimus, nobilissimus, eloquentissimus, iurisconsultissimus, pontifex maximus". ${ }^{8}$ Unfortunately, this galaxy of talents did not include the military arts and Crassus was defeated, assaulting Leucae. Falling into the hands of one of the Thracian bands, Crassus arrogantly abused his captors and blinded one with his riding crop; the Roman general's head was sent to Aristonicus. ${ }^{9}$

At last, the insurgents' naval activity roused the Ephesians who encountered and defeated the rebel fleet off Cyme, ${ }^{10}$ for which Ephesus was rewarded with the governor's seat and the provincial treasury under Roman occupation." With the sea coast lost, Aristonicus fell back on the hinterland and the final phase of his career. The pretender could take some consolation in the battlefield death of King Aria-

1 W. Dittenberger, Orientis Graeci Inscriptiones Selectae, Leipzig 1903, I, pp. 533-537 (No. 338) Despite lacunae, the meaning of the decree is obvious and the final sentence particularly significant. The view that the decree was occasioned by the actual threat of a rebellion already in process is endorsed by T. R. Broughton, An Economic Survey of Ancient Rome (Ed. T. Frank), Baltimore 1938, V, p. 507. Cf. Magie, I, p. 149.

2 Eutropius IV 20. Justin XXXVII 1 . The kings may have feared the example of the Pergamene rebellion on their own slaves, as Vogt (p. 22) suggests, but the more important motive for intervention was the prospect of profit from fishing in troubled waters.

3 Cicero, Phil. XI 8.

4 Justin XXXVI 4 reflects an anti-Crassus tradition not shared by Gellius and Florus.

5 Plutarch, Tiberius Gracchus 2 I.

${ }^{6}$ Valerius Maximus VIII vii 6.

7 Gellius I I3.

8 Ibid.

9 Justin XXXVI 4 and Eutropius IV 20 hold that Crassus died in action. The episode with the Thracians is repeated by Florus I xxxv 20, Orosius V IO, and Frontinus, Strat. IV 5.I 6. Cf. Velleius Paterculus II 4, and Strabo XIV I.38.

${ }^{10}$ Strabo XIV I.38.

1 Tarn, Hell. Civ., p. 173. 
rathes ${ }^{1}$ and the arrival of Blossius of Cumae ${ }^{2}$ who may not have been the only Gracchan extremist to escape the purge and throw in his lot with the Pergamene revolution. "'Going up into the interior", Strabo recounts, Aristonicus "quickly collected a vast number of propertyless men and also slaves bewitched by liberty whom he called Heliopolites."4 The Sun State stormed Apollonis and Thyateira ${ }^{5}$ and might have withstood the client kings and even taken Pergamum; the prospect of sacking the metropolis would suffice to instil ardor into Aristonicus' ex-slaves and former-mercenaries, should Heliopolite appeals fail. However, Rome replaced the late Crassus with a proconsul experienced in subduing rebellious slaves and their self-styled kings.

Though he had reduced the slave insurrection in Sicily and brought "King Antiochus" back in chains, M. Perperna, consul for 130, declined a triumph over chattel ${ }^{6}$ and hastened to Asia where he invested Aristonicus in Stratoniceia on the Caïcus, ${ }^{7}$ starved him into surrender, and sent the fallen Sun King in fetters to Rome. ${ }^{8}$ Familiar with Roman vengeance, Blossius slew himself, ${ }^{9}$ while the burghers of Pergamum held a Soteria joyfully thanking Herakles for their deliverance. ${ }^{10}$ Perperna sent the treasure of Attalus to Rome where it was publicly auctioned with dire effects on the traditional virtues according to the moralists of a later day. ${ }^{11}$ When the consul died in Asia, he was replaced by $\mathrm{M}$. Aquilius who poisoned the springs used by diehard Heliopolites ${ }^{12}$ and was accordingly worshipped as a Benefactor God at Pergamum. ${ }^{13}$ The Senate condemned Phocaea to be razed but relented when Marseilles appealed on behalf of its mother-city. ${ }^{14}$ No such clemency was

1 Justin XXXVII I.

2 Plutarch, Tiberius Gracchus 20. Cicero, de Amic. XI 37.

${ }^{3}$ T. S. Brown, Greek Influence on Tiberius Gracchus, in: Classical Journal, (1947) 42, p. 473. Cicero, de Amic. III I 2 suspects that Gracchans murdered Scipio Africanus the Younger but asserts (XII $4 \mathrm{I}$ ) that friends and relatives of the tribune took vengeance on "Publius Scipio" (= Nasica?). Did Blossius meet Nasica in Asia?

"Strabo XIV 1.38.

${ }^{5}$ Strabo XIV 1.38. J. Swain, Antiochus Epiphanes and Egypt, in: Classical Philology, (1944) 39, pp. 77-78, notes that Aristonicus and Antiochus III used the same stronghold, Livy XXXVII 37 . Both kings posed as champions of the masses and some of Antiochus' propaganda may have taken root in Thyateira.

${ }^{B}$ Florus II vii 19.

? T. R. Broughton, Stratoniceia and Aristonicus, in: Classical Philology, (1934) 29, pp. 252-254. This former site of cistophoric mint was eclipsed until the reign of Hadrian, probably as punishment for harboring Aristonicus.

${ }^{8}$ Eutropius IV 20.

${ }^{9}$ Plutarch, Tiberius Gracchus 20.

${ }^{10}$ Hansen, p. I 47.

11 Florus I xlvii I 2. Pliny, Nat. Hist. XXXIII 149.

12 Florus I xxxv 20.

13 Tarn, Hell. Civ., p. 55. 14 Justin XXXVII I. 
extended to Aristonicus who resigned his claims, ${ }^{1}$ either because of torture or a realistic appraisal of the futility of his cause. It is disputed if he graced the triumph of Aquilius in $126^{2}$ but there is no doubt as to his ultimate fate: "Aristonicus iussu senatus Romae in carcere strangulatus est." 3 'The kingdom, which Aristonicus aspired to inherit, was in the hands of the publicans; the Heliopolis, which he sought to establish, had died stillborn.

II

The significance of the Aristonicus movement is difficult to appraise, for the sources are few, poor, and invariably hostile, primarily epitomizers of the Christian era, late in time and small in mind. Unfortunately the problem has not been resolved by the attention which Aristonicus has received from recent scholars who have not been deterred by the paucity of sources from asserting extraordinary interpretations of the aims and ideological antecedents of the Pergamene pretender. Tarn confidently notes: "It was the only occasion in antiquity on which Homonoia was to extend, not merely laterally - from one race to another-but vertically, to the depths of a slave world; and the moving spirit of it was a king." 4 Toynbee hails Blossius as Marx's "Hellenic prototype" and Aristonicus as "his Pergamene khalifah" 5 and draws attention to the "unmistakable kinship" between Aristonicus and the communist Sheykh Bedr-ed-Din who disturbed Smyrna in A.D. I 41 6. ${ }^{6}$ Pöhlmann was convinced and converted Bidez ${ }^{7}$ and Hansen ${ }^{8}$ that Aristonicus was seeking to realize the romantic Utopia of Iambulus. ${ }^{9}$ While Spengler sourly chided the "Stoic enthusiast, Blossius, who later committed suicide after bringing... Aristonicus of Pergamum to ruin", 10 Kahrstedt soberly detected the sinister specter of a Bolshevik Internationale at work. ${ }^{11}$

Aristonicus' venture into social revolution should not eclipse his rôle as a nationalist opponent of Roman expansion. Because Rome

1 Florus I xxxv 20.

${ }^{2}$ Hansen, p. I48. Velleius Paterculus $I_{4} 4$ is not an unimpeachable source.

${ }^{3}$ Eutropius IV 20.

${ }^{4} \mathrm{~W}$. W. Tarn, Alexander the Great and the Unity of Mankind, in: Proceedings of the British Academy, (1933) 19, P. I31.

${ }^{5}$ Toynbee, V, pp. 179-180.

6 Toynbee, V, p. III, n. 2.

7 J. Bidez, La Cité du Monde et la Cité du Soleil chez les Stoïciens, in: Academie royale de

Belgique, Bulletin de la classe des Lettres, (Ser. 8) (1932) I8, pp. 290-291.

${ }^{8}$ Hansen, p. 144.

9 Pöhlmann, I, p. 4o6. Cf. Oetrel's remarks, II, p. $57^{\circ}$, n. 3.

${ }^{10}$ Oswald Spengler, The Decline of the West, New York I939, II, p. 454.

${ }^{11}$ U. Kahrstedt, Göttingische Gelehrte Anzeigen, (1926) r88, p. 197. 
was at best a unilateral tribute state and more commonly simply grasping, brutal, and inept, her rule was imposed with considerable difficulty on the older nations of the Eastern Mediterranean whose effeteness was belied by Aristonicus, Mithridates Eupator, and Cleopatra. Though the Gracchan program seemed scandalously radical to the Senate, its concept of social justice was limited to Romans not provincials. After Tiberius Gracchus accepted the legacy of Attalus, the Gracchan Crassus came to collect it and Gaius Gracchus would inflict the tax-farmers on Asia. While surely a servile war, the Pergamene rebellion has some affinity with the Italian Revolt of $9 \mathrm{I}$ and in many respects, Aristonicus is closer to Sertorius than to Spartacus.

While on the Mediterranean level, Aristonicus was an Attalid resisting Roman imperialism, he waged class warfare with a vengeance within Pergamum. The pretender exploited not only the traditional protest of the dispossessed poor against the indifferent rich but drew upon all the submerged elements in Pergamene society, the rural serfs against the cities ${ }^{1}$ and the inland Asians against the coastal Greeks. ${ }^{2}$ However, other Hellenistic kings had recently posed as champions of irate commoners to further their political and military ends: Cleomenes III of Sparta, ${ }^{3}$ Perseus of Macedon, ${ }^{4}$ and even the Seleucid Antiochus III the Great. ${ }^{5}$ Other than the encouragement which any challenge to the established order gives to a potential rebel, there is no demonstrable connection between Aristonicus and contemporary slave risings. The egalitarian mood of Heliopolis would hardly have been sustained by a king secure in the Acropolis at Pergamum.

Surely the times were out of joint. While servile disorders were feared and realized, elaborate reforms were sought to ameliorate the plight of dispossessed freemen. At Rome, agrarian capitalism and long campaigning were driving out the small landowner, while the Gracchan program, like the similar archaist appeals of Agis and Cleomenes at Sparta, hoped to retrench the small farmer as the foundation of the state and the strength of the army, ${ }^{6}$ but no attempt was made to cope

${ }^{1}$ Broughton, Economic Survey, IV, p. 509. Rostovtzeff, SEHHW, II, p. I 106.

${ }^{2}$ Compare Saumachus in the Crimea about 109 B.C., which may have been a slave revolt, S. A. Zhebelev, L'abdication de Paerisadès et la révolution Scythe dans le Royaume de Bosphore, in: Revue des Études grecques, (1936) 49, Pp. 17-37. Rostovtzeff, SEHHW, III, p. I512, disagrees.

${ }^{3}$ The myths and realities of Cleomenes III and the Spartan Revolution are examined in my Phylarchus of Athens: History as Propaganda and Tragedy, Berkeley (Calif.) I 96 I.

${ }^{4}$ Livy XuIr 13 . Polibius xxv 3.

${ }^{5}$ Plutarch, Flamininus I 5. Livy XXXV 33-34. His son and general, Mithridates, promised abolition of debts in Lycia, Athenaeus XII $528 \mathrm{~A}$ and Livy XXXIII 19.

- The Gracchans were not Roman populists but patriotic aristocrats trying to raise citizen soldiers on marginal land, Plutarch, Tiberius Gracchus 9 and Appian, Bel. Civ. I I I. 
with the increasing problem of institutionalized slavery which each Roman triumph aggravated by flooding the market with hordes of chattel. As the cleavage between rich and poor became a chasm, the freeman was frequently destitute and politically prostitute, while society in general rested on the highly combustible fabric of mass slavery. "In your country", a Greek remarked to Flamininus, "money alone rules and everything else is subordinate to it." 1 However, Blossius of Cumae did not succumb to the reign of cash.

Despite attempts to provide him with a Campanian lineage on the basis of an atavistic propensity to arson and insurrection, ${ }^{2}$ the antecedents of Caius Blossius remain as enigmatic as the man himself. Nevertheless, he was a hospes of the family of M. Scaevola, ${ }^{3}$ which no doubt stood him well in the purge of 132 . A pupil of Antipater of Tarsus and an associate of Panaetius and Diophanes of Mitylene, ${ }^{4}$ Blossius was probably aware of the volatile situation in the East and possibly even in contact with its leaders. Surely his defection to Aristonicus was based on some knowledge of the pretender's aims, for he by-passed the slave king, Eunus, whose Sicilian stronghold would have been a convenient haven for a really radical émigré. However, as the Gracchan ideologue, Blossius was unconcerned with slaves and no doubt saw in Aristonicus another popular tyrant like Tiberius Gracchus, liberal in terms of his times, but, despite appearances, in the tradition of the gentleman benefactor like the father of the tribunes, T. Semperonius Gracchus, who had championed the Iberian natives against Roman brutality and cupidity. ${ }^{5}$ Cicero, who noted his unhappy end with approval, castigated Blossius as the evil genius of Tiberius Gracchus: "Non enim paruit ille Ti. Gracchi temeritati, sed praefuit, nec se comitem illius furoris, sed ducem praebuit."' Plutarch credited him and Diophanes with instigating the land program and recounted how the Stoic brazenly scoffed at ill omens which shook the confidence of the tribune. ${ }^{7}$ As the energetic defender and possible creator of the Gracchan concept of the tribunate as a popular tyranny, Blossius is ill cast in the rôle of anti-Roman Italian separatist. After the murder of

1 Livy XXXIV 31.

${ }^{2}$ D. Dudley, Blossius of Cumae, in: Journal of Roman Studies, (194I) 31, p. 95.

3 Cicero, de Amic. XI 37.

4 Plutarch, Tiberius Gracchus 8. Panaetius studied at Pergamum under Crates, Hansen, p. 383 .

${ }^{5}$ Plutarch, Tiberius Gracchus 5. The grandfather of the tribunes had raised two legions of slaves freed on condition that they fight Hannibal. Livy XXII 57; Valerius Maximus VII vi $\mathrm{I}$.

${ }^{6}$ Cicero, de Amic. XI 37.

7 Plutarch, Tiberius Gracchus 8; 7 . Plutarch permits the blasphemy against omens because they came true. Cf. Pericles 6. 
Tiberius Gracchus, the Senate scrupulously purged the radical wing of the popular party but daintily ignored the better-born Gracchans, Scaevola, Crassus, and Gaius Gracchus. At a preliminary hearing of the special tribunal attended by the consuls, P. Laenas and P. Rupilius, G. Laelius, ${ }^{1}$ and possibly Nasica, Blossius was asked if he would have obeyed Tiberius Gracchus' command to fire the Capitol, an injunction which would have nullified the tribune's powers according to the theory of the tribunate formulated by the Gracchans against M. Octavius. ${ }^{2}$ With greater valor than tact, Blossius placed personal loyalty before ideological consistency and replied in the affirmative. ${ }^{3}$ However, despite this inflammatory remark, he was permitted to flee from Rome and escape the fate of Diophanes, which would suggest that some degree of concern for him in high places proposed the arson question as an escape and not a trap; Plutarch even claims that he was pardoned. 4 The adherence of a man of such courage and convictions speaks well for Aristonicus.

\section{III}

Though history has preserved the measurements of Saint John's New Jerusalem, only the name remains of Aristonicus' City of the Sun, a defect which some propose can be filled by Iambulus' tale of the Isles of the Sun. ${ }^{5}$ With doubtful fidelity, Diodorus has preserved an account of Iambulus' sojourn in a pleasant archipelago in the Indian Ocean where, amid the natural abundance proverbial in equatorial climes, a happy race of polyglot, industrious, and serene sun worshippers, addicted to eugenics, euthanasia, and astrology, spend their days in easy alternating labor, free from the scourges of slavery and monogamy. ${ }^{6}$ However, the proportion of Utopian allegory to geogra-

${ }^{1}$ Laelius had earned the epithet "Sapiens" by avoiding arguments with the opposition over land reform, Plutarch, Tiberius Gracchus 8.

2 Plutarch, Tiberius Gracchus I9. A similar notion that legality was dependent on the public interest is attributed to King Agis IV of Sparta, Plutarch, Agis 12.

3 Plutarch, Tiberius Gracchus 20. Cicero, de Amic. XI 37. Valerius Maximus IV vii I.

4 Plutarch, Tiberius Gracchus 20. Though Nasica first asked the question, it was "repeated often and by many persons". A similar escape is offered to Agis at his trial, Plutarch, Agis I 9 .

5 Pöhlmann, I, pp. 405-406; II, pp. 305-324. Kroll, Iambulos, in: Real-Encyclopädie der cl. Alt., IX, pp. 65 I-655. Bidez, pp. 280-283, 290-291. Tarn, Alexander Helios and the Golden Age, in: Journal of Roman Studies, (1932) 22, p. 140. H. Last, in: Cambridge Ancient History, IX, p. 104. The view that Iambulus depicted a Stoic Utopia is related to the unwarranted assumption that Stoicism was a semi-socialist creed, on which see my "Stoics, Cynics, and the Spartan Revolution, in: International Review of Social History, (1959) IV, pp. 461-469 and H. Baldry, Zeno's Ideal State, in: Journal of Hellenic Studies, (1959) 79, pp. 3-15.

B Diodorus II 55-60. The astral symbolism of the seven circular islands does not prove Stoic influence, since astrology was the accepted pseudo-science of the Hellenistic era and one of the few intellectuals to challenge it was the Stoic Panaetius, Cicero, de Div. II 88. 
phic romance cannot be resolved from a fragment preserved by a notoriously inept compiler. The society of the Isles of the Sun was monarchical, kin-based, and reverent of age and, with its communal marriage and carefree life amid lush flora and exotic fauna, did not vary much from the conventional Greek notions of Indic bliss, remote from the social afflictions of the Hellenistic world. ${ }^{1}$ Like Montaigne's cannibals, Iambulus' happy Indians are a romanticized composite of travellers' tales, held up as an existent ideal to mortify corrupt Europeans, and the Isles of the Sun are closer to Melville's Typee than to More's Utopia. Except for a terminus in Diodorus, it is difficult to date Iambulus, though Rose has scented a familiarity with Poseidonius. ${ }^{2}$ However, Tarn is sure that the influence is Eratosthenes, though he considers this argument of less weight than the tautology that, since Iambulus was constructing a Utopia, he must belong to the "constructive period of Hellenistic thought", i.e. the Third Century. ${ }^{3}$ Even if Iambulus was known to Aristonicus and considerably more impressively than in Diodorus' version, a literary parable would hardly provide a workable program for a struggling revolution much less suffice to inflame an illiterate peasantry.

In the ancient Near East, there were real cities of the Sun, venerable shrines of solar worship, notably Egyptian On and Syrjan Baalbek. ${ }^{4}$ With his proclamation of another Heliopolis, Aristonicus aimed at a religious appeal, intelligible to the oppressed natives who flocked to his standard. Not only a tangible deity, the sun is the very source of life, "Helios, whom the wise men call the king of the gods and the

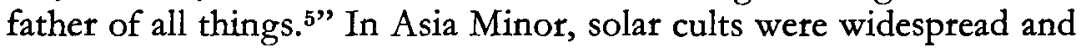
Greek Apollo himself was an Anatolian immigrant. ${ }^{6}$ At Hiera Kome, near Aristonicus' stronghold at Thyateira, the priests of the "Persian goddess" preached Mithraic Fifth Monarchy propaganda against the Seleucids. ${ }^{7}$ Even into modern times, politics and religion have been

\footnotetext{
I See Diodorus II 39-41, or Strabo XV 1.34.

${ }^{2} \mathrm{H}$. Rose, The Date of Iambulos, in: Classical Quarterly, (1939) 33, pp. 9-10.

${ }^{3}$ W. Tarn, The Date of Iambulos, in: Classical Quarterly, (1939) 33, p. 193.

${ }^{4}$ In the Hellenistic era, On was chiefly of antiquarian interest, but Theodor Mommsen, Römische Geschichte, Berlin i 874, II, p. 54, has suggested a connection between Aristonicus and the Syrian sun cult, a relation more applicable to Eunus in Sicily where there was an obvious Syrian factor operative in the slave revolt.

${ }^{5}$ A fragment, probably of Sophocles, quoted by Jane Harrison, Prolegomena to the Study of Greek Religion, Cambridgc (Ed. 3) I922, p. 462. Cf. Aristophanes, Peace 404ff.

${ }^{6}$ W. K. Guthrie, The Greeks and their Gods, Boston 1950, pp. 84-86.

7 J. Swain, The Theory of the Four Monarchies, in: Classical Philology, (1940) 35, pp. I I-I 2, and Antiochus Epiphanes and Egypt, in: Classical Philology, (1944) 39, p. 78 suggests that Aristonicus utilized an Anatolian solar cult. Tacitus calls the deity at Hiera Kome "the Persian Artemis", Annals III 62, but she would be the just Sun of Arinna, whatever she meant to the Magi. Herodotus I I3 I confused Mithra with the "Persian Aphrodite".
} 
inseparable in contested Asia Minor. Toiling for royal master or city nabob, the Asian serf knew only one benevolent force in his daily struggle with poverty and drudgery, the Sun who shines on rich and poor alike and whose blazing eye observes each injustice of the world below. At Delphi, Apollo was the protector of the liberated slave ${ }^{1}$ and guaranteed the limits of his new status. ${ }^{2}$ In Thrace, Helios was particularly popular ${ }^{3}$ and the support of Thracian mercenaries was vital to Aristonicus. With the fleet gone and the cities alienated, the pretender was forced to rely on the serfs of the Anatolian countryside and the dispossessed of society in general, the special suppliants of Helios Dikaiosynes, ${ }^{4}$ to whom Utopian brochures meant nothing. The thickfingered agrarian proletariat could not respond to incomprehensible programs for future happiness or glib descriptions of faraway bliss, but they would hearken readily to appeals to known and trusted gods, especially the Sun whose virtue quickened the seed and warmed the earth, the Benefactor who took no tax, the Savior who rose each day, the truly Manifest God. The Greek Strabo calls him Helios, ${ }^{5}$ just as Caesar and Tacitus label Gallic and German deities by more familiar names, but the title would suffice only for the Hellenized element in Aristonicus' following who had fled from Pergamum and the other Greek cities. To the country folk, the Sun God of their fathers was still manifest. When Herodotus saw his form near Smyrna and by Ephesus, he confused the god with the legendary Sesostris because of what he fancied were Egyptian hieroglyphics, ${ }^{6}$ in reality Hittite inscriptions. Like the Babylonian Shamash, the Hittite Sun God was a protector of right, "a shepherd of mankind... O Sun God of

${ }^{1}$ L. Farnell, The Cults of the Greek States, Oxford x907, IV, pp. I77-1 79.

2 W. Westermann, The Slave Systems of Greek and Roman Antiquity, Philadelphia 1955 , pp. 35, but see the comment of M. I. Finley, The Servile Statuses in Ancient Greece, in: Revue Internationale des Droits de l'Antiquité (1960, Ser. 3), 7, pp. 183-1 84 .

${ }^{3}$ Harrison, p. 462.

4 Rostovtzeff, SEHHW, II, p. 808. Dudley, p. 99. However, Tarn, reviewing Rostovtzeff in Journal of Roman Studies, (1941) 31, pp. 165-171, feels that no one would fight for an abstract Sun of Righteousness.

${ }^{5}$ Strabo XIV 1.38. Though Pontine by birth, Strabo was culturally a Greek and gave Aristonicus' sun god a familiar Greek name. 'Throughout this paper, the term "Asian" implies geography and only such cultural differences as might arise from that factor. The East contained more cultural debris and live fossils than the West but the human elements were the same: Ulpian and Elagabalus were both Syrians, as were the skeptic Lucian and the theologian Paul of Samosata.

- Herodotus scoffs at the suggestion that the statue was of Memnon, II ro6. Even the Weather God of Hatti (the consort of the Sun of Arinna) could pass for Aristonicus' solar patron; the farmers, to whom the images were familiar for centuries, were syncretists by necessity. For "Niobe" and other Hittite archeological and cultural relics, see George Thomson, Studies in Ancient Greek Society, London 1954, Vol. I(The Ancient Aegean), pp. 406-407. 
heaven, my lord, daily thou sittest in judgement upon man, dog, pig, and the wild beasts of the field." 1 To the Hittites and to their cultural descendants, the Sun warranted the address: "The inspired lord of justice art thou, and in the place of justice thou art untiring."2 For the more sophisticated Heliopolites, Blossius could point out that the firm justice, presumably radiated by the god-king of Egypt, was in reality the solar energy of his heavenly father. ${ }^{3}$ However, like Sertorius' magic deer, Heliopolis was for local consumption and can only be distorted by excessive intellectualization. ${ }^{4}$

Presumably Aristonicus aimed at public welfare and the betterment of the Pergamene poor but within the contemporary framework of monarchy, a benevolent despotism (at least in prospect) with the king no longer the shearer but the shepherd of his flock. Apart from the immediate violence of the class war, the bourgeoisie of Pergamum feared confiscation of their wealth, not universal suffrage, for Aristonicus threatened, not social democracy, but redistribution of the profits of society, a by no means unique occurrence in Greek history. ${ }^{5}$ Perhaps with success the pretender might have proved more king than benefactor, since he saw himself as a prince unjustly deprived of a rightful throne by a wicked relative, a not unusual situation in Near Eastern fact and legend. While he challenged an oppressive social order and the imperial might of Rome, Aristonicus embodied both the Hellenistic ideal monarch counselled by a sage and the vastly older tradition of the hidden hero, a king's son of doubtful birth, raised in

${ }_{1}^{1}$ O. R. Gurney, The Hittites, London 1952, p. 139. When Suppiluliumas, the father of Mursilis II, adopted the title of Sun and the solar disc as a royal symbol, no doubt his friend, Akhenaton, impressed upon him the moral qualities of the Sun God.

2 Ibid., p. 139. Indigenous to the West coast of Asia Minor, the Sun is also called "Sun-god in the Waters" by the Hittites. Strabo testifies to his continued populariry in the region, XIII 2.5. At Troy, Apollo fought for Asia against Europe. His name may derive from the Hittite Apulunas, Martin Nilsson, Greek Popular Religion, New York 1940, p. 79, but see R. D. Barnett, Journal of Hellenic Studies, (1950) 70, p. I04.

${ }^{3}$ E. Goodenough, The Political Philosophy of the Hellenistic Kingship, in: Yale Classical Studies, (1928) I, p. 82. Vogt's suggestion (p. 36) to connect Heliopolis with Alexarchus of Uranopolis and Zeus Menecrates is unfortunate. Both men were mad and the latter may not have existed. The Heavenly City of Alexarchus was an idee fixe humored by his brother, King Cassander, while the anecdotes of Menecrates suggest a lampoon on the pretensions of both Hellenistic divine monarchy and the medical profession, Strabo VII 35, Athenaeus III 98 D-F VII $289 \mathrm{~A}-\mathrm{F}$.

4 Plutarch, Sertorius I I, 20. Sertorius' wish to escape to the Isles of Paradise (18-19) is aimed by Plutarch at Roman readers; the sacred deer, however, was a legitimate mantic device of the leader who lived among the Iberians as one of their own, wearing their garb and respecting their habits.

${ }^{5}$ Polybius XV 2 I dourly remarks: "The chief object in every civil strife is to change fortunes." 
obscurity and striving to wrest his father's throne from usurpers. Probably Aristonicus hoped to realize the aim of "perpetual peace for his subjects and swift redress in his courts" I but he also knew that the son would come into his kingdom only as the Sun in his zenith.

In Eastern folklore, the tales of kings outlast their inscriptions and official annals; the Horned Iskandar and his Wazir Aristu built the Great Wall of China to contain Gog and Magog. ${ }^{2}$ For three millenia, Gilgamesh survived, not as the epic symbol of man's mortality, but as the infant prince who escaped the murderous designs of his evil grandfather to be raised in obscurity. ${ }^{3}$ To emulate the great Semitic conqueror Sargon, Hebrew national pride cast the baby Moses adrift in the river, ${ }^{4}$ secure in the knowledge that castaway kings will still achieve their destiny like Cyrus, Theseus, and a host of hidden heroes. Like the physical ruins of Hittite grandeur, the relics of Hittite thought and history survived in Asia and even in Greece where Kronos and Uranos acted out the Hittite myth of Kumarbi's castration of Anu. ${ }^{5}$ His birthright seized by Rome, Aristonicus could well cast himself in the rôle of the Hittite monarch, Mursilis II, whose adventures refracted through folk romances could hardly surpass his own testimony:

"When I the Sun seated myself upon my father's throne, before I moved against any of the hostile countries which had declared war upon me, I attended to the recurrent festivals of the Sun-goddess of Arinna... and spoke thus: 'Sun-goddess of Arinna, my

${ }_{1}$ This ideal was vainly addressed to the Ptolemaic government by the apocryphal Letter of Aristeas $29 \mathrm{r}$. See the comment of T. A. Sinclair, A History of Greek Political Thought, London 1951, p. 293, n.I.

2 Richard Burton, The Book of the Thousand Nights and a Night, New York 1934, III, pp. I 893-1894. Martin Braun, History and Romance in Graeco-Oriental Literature, Oxford $193^{8}$, emphasizes the nationalist tone of such pseudo-factual figures as Semiramis and Nectanebo. In the Hellenistic era, much ancient history was revived and adapted for contemporary tastes by writers like Manetho, Berossus, and the authors of the Pentateuch, not necessarily with any greater accuracy than what was the common property of the village storytellers.

3 Aelian, de nat. anim. XII 2 I preserves the Gilgamesh tale in the Third Century A. D. See Thorkild Jacobsen, The Sumerian King List, Chicago I939, pp. 89-91.

4 The legendary Sargon describes how "my changeling mother bore me; in secret she bote me. She set me in a basket of rushes; with bitumen she sealed my lid. She cast me into the river which rose not over me... and carried me to Akki, the drawer of water,... [ $\mathrm{who}$. lifted me out... and reared me." James B. Pritchard, Ancient Near Eastern Texts relating to the Old Testament, Princeton, (Ed. 2) I955, p. 1 I9. Cf. Exodus 2.2-6.

${ }^{5}$ R. D. Barnett, The Epic of Kumarbi and the Theogony of Hesiod, in: Journal of Hellenic Studies, (1945) 65, pp. го0-IоI. H. G. Güterbock, The Hittite version of the Hurrian Kumarbi Myths: Oriental Forerunners of Hesiod, in: American Journal of Archeology, (1948) 52, Pp. I23-134. Thomson, pp. I79-183, discusses the Hittite background of the Amazon legend. See Hansen, pp. 395-396, 400, for Hittite cult survivals at Pergamum. 
lady, the surrounding hostile countries which called me a child and made light of me and were constantly trying to seize thy territories... - come down, o Sun-goddess of Arinna, my lady, and smite these hostile countries for me.' And the Sun-goddess of Arinna heard my prayer and came to my aid, and in ten years from the time when I sat down on my father's throne I conquered those hostile countries and destroyed them." 1

However, Aristonicus did not have ten years and the Sun State died with him in a Roman dungeon.

1 Gurney p. I74. Mursilis too was a younger son whose throne was threatened by aggression from the West. By assuming the title of "Sun", he absorbed the aura of justice which surrounded the Sun of Arinna in both its masculine and feminine forms. Mursilis' son, Muwatallis, was the host of Paris and Helen in their flight from Sparta, Gurney, pp. 57-58. Later tradition knew "Myrsilus" as the last of the Heracleidae to rule Lydia, Herodotus I 7 . 